\title{
Principals' Perception of Misconduct among Secondary School Teachers in Delta State: Implications for Counselling Practice
}

\author{
Anna Onoyase ${ }^{1}$, Ph.D. \\ ${ }^{1}$ Department of Guidance and Counselling,Delta State University, Abraka, Nigeria \\ Correspondence: Anna Onoyase, Ph.D., Department of Guidance and Counselling, Delta State University, P.M.B. 1, \\ Abraka, Nigeria
}

Received: September 7, 2018

Accepted: October 3, 2018

Online Published: October 10, 2018

doi:10.5430/ijhe.v7n5p150

URL: https://doi.org/10.5430/ijhe.v7n5p150

\begin{abstract}
This study investigated Principals' Perception of misconduct among Secondary School teachers in Delta State. Four research questions and four hypotheses were formulated to guide the study. The instrument used for collection of data was tagged "Principals' Perception of Teachers Misconduct Questionnaire" (PPOTMQ). For content validity, the instrument was given to some lecturers in the Department of Guidance \& Counselling who scrutinized it and made some corrections. The test-retest method of reliability was employed and the co-efficient of 0.72 was obtained. The sample consisted of 100 principals. The t-test statistics was employed to test the hypotheses at 0.05 level of significance. Results of the study revealed that absenteeism, lateness, truancy and poor quality teaching were perceived by principals as forms of misconduct in public secondary schools. Recommendations that were proffered include; monitoring teams should be put in place by school authorities to supervise teachers' attendance in class as well as their teaching, inspectors from the Post-Primary Education Board should pay regular unscheduled visits to secondary schools to act as a check on teachers' absenteeism.
\end{abstract}

Keywords: misconduct, absenteeism, lateness, truancy and poor quality teaching.

\section{Introduction}

Education is regarded as a powerful tool for the development of individual citizens of a country and the country as a whole. The broad objectives of secondary education in Nigeria as stated in the National Policy on Education (2016) are; preparing students for useful living within the society and attaining higher education. There is no gainsaying the fact that if these laudable goals are realized, individuals will not only be useful to themselves and their families but will also contribute their quota to the development of this country in every ramification. Admittedly, the executioners of these goals are teachers. In fact, teachers are the pivot on which the educational system rests and so they are indispensable in the educational sector. Undoubtedly, teachers are the human resources needed to impart knowledge to students and to inculcate the right morals in them. According to Fakoya (2009), the business of teachers is to help students to achieve higher standards of knowledge, ability, skills and moral character.

After the attainment of independence in 1960 until the early 80's, Nigerian teachers (primary and secondary) were very dedicated to their duties; their level of commitment was high and were greatly motivated. Buttressing this point, Onoyase (2000) opined that in the 70's, the standard of education was high because teachers devoted much time and energy to teaching, not because the condition of service was very attractive but just for the sake of imparting knowledge to the young ones. Continuing, she stated that these teachers organized evening lessons free of charge and tirelessly taught pupils good handwriting. Still on teachers' attitude to work, Solarin and Akinsanya (1982) as cited in Aronokhale (1999) observed that before independence and even shortly after, Nigerians (including teachers) diligently went about their assigned jobs, be it government services or private sector, from dawn to dusk. From observation, teachers are no longer as dedicated as were their counterparts of old. Commenting on this, Teachers' Registration Council of Nigeria (TRCN) (2012) opined that the history of education in Nigeria indicate that teachers epitomized integrity, knowledge, selfless service and moral rectitude, but over the years the reverse appeared to be the case. The euthusiasm, commitment and dedication of yester years of teachers seemed to have given way to negative work behaviours such as lateness, absenteeism, truancy, and poor quality teaching. Invariably, these indices of misconduct will diminish teachers' productivity and adversely affect the products of this level of education. 


\section{Related Literature}

Rossouw (2013) opined that the incidences of misconduct among teaching staff in public secondary schools in South Africa is increasing at an alarming rate and that cases of misconduct include insubordination, dishonesty, absenteeism and late coming amongst others. It is now a common occurrence among some workers to keep away from work for many days within a month and receive their salaries at the end of the month without thinking of the consequences of their action on the organization (Ukoeshi, 1984 in Adeleke, 2000),

Other forms of misconduct include truancy, persistent lateness, theft, poor quality teaching, failure to write lesson notes and insubordination to constituted authority. Adeleke (2000) reiterated that truancy and persistent lateness are indicators of decreased commitment of the Nigerian worker and that if left unchecked, this negative attitude can account for low productivity. Oghuvwu \& Okpilike (2012) observed that there are some unethical conducts among teachers in schools and that they include truancy, lateness to school, drug abuse and improper dressing.

The misconduct of teachers was also observed by the West African Examination Council. WAEC (2009) noted that more candidates fail in their examination due to lack of quality teaching compared to what most adults got during their school days. WAEC also discovered that candidates fail examination because they and their teachers hardly read nor make use of WAEC syllabus as a guide. From experience, the researcher has observed that some teachers in public secondary schools deliberately hawk different kinds of wares during official hours instead of teaching their lessons. According to Kazeem \& Ige (2010), when these tutors eventually settle to teach, they hardly have enough time to cover the syllabus and consequently organize "extra lesson" with its attendant financial implications (on parents) to make up for lost time. Again, Akinlabi (2012) reported that many teachers in secondary schools are now too big to stand for forty-five minutes to teach a lesson. Furthermore, he observed that teachers take delight more in discussing under trees and analyzing situations (such as government policies, politics, football and even marital issues) instead of teaching their lessons. It has to be pointed out that while these tutors are busy discussing these irrelevancies; they send notes to class prefects to copy on the board for their classmates. One therefore begins to wonder whether note taking has taken the place of teaching in our secondary schools.

Fry, (2002) observed that there is growing government and public concern over the prevalence of misconduct among college teachers in Tanzania and that such misconduct may be viewed as a means of livelihood strategy for coping with demanding jobs when living conditions are difficult. In other words, teachers become irregular in school so as to look for other sources of income to make both ends meet. In 1995, a World Bank survey carried out in Tanzania revealed that $38 \%$ of teachers were absent for a minimum of two days in the primary school previous Week (Schleicher, Siniscalco and Postlethwaite, 1995). The survey also reported that a large proportion of absence are for legitimate reasons such as illness or attendance at in-service training but that teachers' truancy featured in interviews with Inspectors and Education officers. UNESCO (2005) Global monitoring report revealed high level absenteeism in Tanzania which it attributed to professional standards and lack of support or control by education authorities.

Mothermane, (2004) undertook a research on how principals manage educators' (teachers) misconduct in public secondary schools in Bochum district, Limpopo province (one of the nine provinces in South Africa). Nine out of the ten schools in the district were used. The researcher used the interview method and the same questions on how principals manage educators' misconduct were posed to both principals and educators. The results revealed that late coming is the most common form of educator misconduct in the schools that participated in the study. Furthermore, the findings indicated that absenteeism ranked next to late coming and that both forms of misconduct are more frequent on Mondays and Fridays. The reasons one may adduce for the lackadaisical attitude of secondary school teachers to work in Nigeria are wrong orientation about government's work, poor supervision, lack of adequate motivation, poor work environment and job dissatisfaction.

\section{Statement of the Problem}

In the distant past in Nigeria, professional misconduct among teachers was uncommon. Presently, it is now a serious problem that seems to have defied all solutions. In most public secondary schools, tutors hardly resume work at 8.00am and even some of them who arrive late, sooner or later leave their duty post in the guise of going to pick one thing or the other. Sadly enough, Fridays are gradually becoming non-working days in Nigeria, in government institutions (including public secondary schools) because of marriages or burial ceremonies. Moreover, some teachers deliberately stay away from work for selfish reasons without permission or official notification. Inadequate preparation for lessons and failure to write lesson notes also seem to reveal the lack of commitment of secondary school teachers to their work. The problem of this study therefore is to determine the existence of misconduct among secondary school teachers from principals' opinions and critically discuss how counsellors can effect a change in the attitude of these teachers. 


\section{Research Questions}

Four research questions were raised to guide the study:

1. Is there any difference between male and female principals' perception of teachers' absenteeism as a form of misconduct in secondary schools?

2. What is the difference between older and younger principals' perception of teachers' lateness as a form of misconduct in secondary schools?

3. Is there any difference between rural and urban principals' perception of truancy as a form of misconduct in secondary schools?

4. What is the difference between experienced and less experienced principals' perception of teachers poor quality teaching as a form of misconduct in secondary schools?

\section{Hypotheses}

Four hypotheses were formulated for the study and these include the followings;

$\mathrm{HO}_{1}$. There is no significant difference between male and female principals' perception of teachers' absenteeism as a form of misconduct in secondary schools.

$\mathrm{HO}_{2}$ : There is no significant difference between older and younger principals' perception of teachers' lateness as a form of misconduct in secondary schools.

$\mathrm{HO}_{3}$ : There is no significant difference between rural and urban principals' perception of truancy as a form of misconduct in secondary schools.

$\mathrm{HO}_{4}$ : There is no significant difference between experienced and less experienced principals' perception of teachers' poor quality teaching as a form of misconduct in secondary schools.

\section{Objectives of the Study}

The objectives of the study are as follow:

1. To determine the existence of misconduct among secondary school teachers.

2. To use counselling techniques to assist teachers develop positive work habits that will increase their productivity.

\section{Research Method and Procedure}

The descriptive Survey research design was adopted to elicit information from the respondents using the questionnaire. The population comprised all principals in Delta Central Senatorial District. The instrument used for the collection of data was tagged 'Principals' Perception of Teachers' Misconduct Questionnaire" (PPOTMQ) and was made up of twenty items. For content validity, the instrument was given to four lecturers in the Department of Guidance \& Counselling who scrutinized and made necessary corrections. The reliability coefficient of 0.72 was obtained, using the test-retest method at 0.05 level of significance. This is an indication that the instrument is reliable and suitable for data collection. The questionnaire comprised two sections; section A contained questions on biographic data of subjects such as gender, age, level of experience and nature of school (rural and urban) while section B consisted of 20 items indicative of professional misconduct of teachers. The questionnaire items include the following: "Absenteeism of teachers in secondary schools is on the increase," "Teachers are not perturbed about their persistent lateness to school," "Sneaking out from school by teachers is seen as a "normal" practice". The researcher used the random sampling technique to select three from eight local government areas in Delta Central Senatorial District. All the principals in public secondary schools in the three local government areas - Ughelli North, Ethiope West and Uvwie, totaling one hundred and twenty five (125) principals were used. Three research assistants aided the investigator in the administration of the instrument and one hundred (100) principals returned their questionnaire showing $80 \%$ retrieval rate. The researcher then utilized the t-test statistical method to test the hypotheses at 0.05 level of significance.

\subsection{Definition of Terms}

The terms below have been defined operationally.

Misconduct: Misconduct refers to negative behaviour exhibited by secondary school teachers.

Older principals: These are principals who are between 55 and 60 years of age.

Younger Principals: These are principals whose age range from 48years to 55 years of age. 
Urban Principals: Urban principals are heads of post-primary institutions whose schools are located in towns with basic amenities such as electricity, water and good roads.

Rural Principals: Rural principals are principals whose schools are situated in villages where there is no electricity, pipe-borne water or good roads.

Experienced Principals: These are principals who have been heading schools for a period of over 10 years.

Less experienced Principals: This category of principals has leadership experience below 5 years.

\section{Presentation of Results and Discussion}

The findings of the study have been reported in four tables as follows:

\section{Research Question One}

Is there any difference between male and female principals' perception of teachers absenteeism as a form of misconduct in secondary schools?

\section{Hypothesis One}

There is no significant difference between male and female principals in their perception of teachers' absenteeism as a form of misconduct in secondary schools.

Table 1. T-test Analysis of Male and Female Principals' perception of teachers' absenteeism as a form of misconduct in secondary schools.

\begin{tabular}{lcccccccc}
\hline \multicolumn{1}{c}{ Variables } & N & $\bar{X}$ & SD & Df & t-cal & & t-critical & $\begin{array}{c}\text { Level of } \\
\text { significance }\end{array}$ \\
\hline Male principals & 63 & 14.95 & 2.40 & 98 & 0.837 & 2.000 & 0.05 & Not significant \\
Female Principals & 37 & 14.46 & 3.48 & & & & (accepted) \\
\hline
\end{tabular}

$\mathrm{P}>.05$ level of significance

Table 1 has indicated a difference in the mean perception of male and female principals regarding absenteeism as a form of misconduct in secondary schools. The difference is not however significant because the t-calculated value of 0.837 is less than the t-critical value of 2.000 . Hence, the null hypothesis was accepted. This implies that there was no significant difference between male and female principals' perception of teachers' absenteeism as a form of misconduct in secondary schools.

\section{Research Question Two}

What is the difference between older and younger principals' perception of teachers' lateness as a form of misconduct in secondary schools?

Table 2. T-test Analysis of Older and Younger Principal's perception of teachers' lateness as a form of misconduct in secondary schools.

\begin{tabular}{lcccccccc}
\hline \multicolumn{1}{c}{ Variables } & N & $\bar{X}$ & SD & Df & t-cal & & t-critical & $\begin{array}{c}\text { Level of } \\
\text { significance }\end{array}$ \\
\hline $\begin{array}{l}\text { Older (Principals) } \\
\text { (55-60yrs) }\end{array}$ & 45 & 14.16 & 2.66 & 98 & 0.236 & 2.000 & 0.05 & $\begin{array}{c}\text { Not significant } \\
\text { (accepted) }\end{array}$ \\
$\begin{array}{l}\text { Younger Principals } \\
(48-55 \text { years) }\end{array}$ & 55 & 14.02 & 3.08 & & & & \\
\hline
\end{tabular}

$$
\mathrm{P}>.05 \text { level of significance }
$$

On table 2, the t-calculated value of 0.236 was lower than the t-critical value of 2.000 . Therefore, the null hypothesis was retained. This revealed that there was no significant difference between older and younger principals' perception of teachers' lateness as a form of misconduct in secondary schools.

\section{Research Question Three}

Is there any difference between rural and urban principal's perception of truancy as a form of misconduct in secondary schools? 
Table 3. t-test Analysis of Rural and Urban Principals' perception of truancy as a form of misconduct in secondary schools.

\begin{tabular}{|c|c|c|c|c|c|c|c|c|}
\hline Variables & $\mathbf{N}$ & $\bar{X}$ & SD & Df & t-cal & t-critical & $\begin{array}{c}\text { Level of } \\
\text { significance }\end{array}$ & Decision \\
\hline Rural Principals & 23 & 14.04 & 3.08 & \multirow[t]{2}{*}{98} & \multirow[t]{2}{*}{1.370} & 2.000 & \multirow[t]{2}{*}{0.05} & \multirow{2}{*}{$\begin{array}{l}\text { Not significant } \\
\text { (accepted) }\end{array}$} \\
\hline Urban Principals & 77 & 13.18 & 2.51 & & & & & \\
\hline
\end{tabular}

An inspection of table 3 showed that there is a difference in the mean perception of rural and urban principals as regards truancy as a form of misconduct in secondary schools. But the difference is not significant as the t-calculated value of 1.370 was less than the t-critical value of 2.000 . Therefore, the null hypothesis was accepted. This shows that there was no significant difference between Rural and Urban Principals' perception of truancy as a form of misconduct in secondary schools.

\section{Research Question Four}

What is the difference between experienced and less experienced principals' perception of teachers' poor quality teaching as a form of misconduct in secondary schools?

\section{Hypothesis Four}

There is no significant difference between experienced and less experienced principals' perception of teachers' poor quality teaching as a form of misconduct in secondary schools.

Table 4. t-test Analysis of Experienced and Less Experienced Principals' perception of teachers' poor quality teaching as a form of misconduct in secondary schools.

\begin{tabular}{|c|c|c|c|c|c|c|c|c|}
\hline Variables & $\mathbf{N}$ & $\bar{X}$ & SD & Df & t-cal & t-critical & $\begin{array}{c}\text { Level of } \\
\text { significance }\end{array}$ & Decision \\
\hline $\begin{array}{l}\text { Experienced Principals } \\
\text { (Over } 10 \text { years } \\
\text { experience) }\end{array}$ & 59 & 13.20 & 2.45 & 98 & 1.454 & 2.000 & 0.05 & $\begin{array}{l}\text { Not significant } \\
\text { (accepted) }\end{array}$ \\
\hline $\begin{array}{l}\text { Less experienced } \\
\text { Principals (below } 5 \\
\text { years experience) }\end{array}$ & 41 & 12.51 & 2.17 & & & & & \\
\hline
\end{tabular}

\section{$\mathrm{P}>.05$ level of significance}

The data on table 4 revealed a difference between experienced and less experienced Principals perception of teachers' poor quality teaching as a form of misconduct in secondary schools. This is so because the calculated t-value of 1.454 is less than the critical t-value of 2.000 at 0.05 level of significance. Therefore, the null hypothesis was retained.

\section{Discussion}

The research has revealed that there is no significant difference between male and female principals' perception of teachers' absenteeism as a form of induct in secondary schools. This is in line with Ukoeshi (1984) and Adeleke (2000) who opined that it is now a common practice among workers in Nigeria (including secondary school teachers) to keep away from work for many days within a month without thinking of the consequences of their action on the organization. Furthermore, the study supports UNESCO's (2005) Global monitoring report which revealed a high level of absenteeism among teachers in Tanzania.

Another finding of this study has indicated that there is no significant difference between older and younger principals' perception of teachers' lateness as a form of misconduct in secondary schools. This corroborates the view of Adeleke (2000) who emphasized that persistent lateness of workers in Nigeria is an indication of their decreased commitment. The result also supports the research of Mothermane (2004) which revealed that lateness is the most common form of Educator misconduct in Bochum district (Liropopo Province), South Africa and is more frequent on Mondays and Fridays.

The investigation has also found out that there is no significant difference between rural and urban principals' perception of truancy as a form of misconduct in secondary schools. This agrees with Oghuvwhu and Okpilike (2012) 
who observed with dismay some of the unethical conduct in schools and identified truancy and lateness as some of them. This finding also gives credence to Adeleke (2000) who decried the incidence of truancy in schools and emphasized that if left unchecked could account for low productivity.

The last finding of this study has shown that there is no significant difference between experienced and less experienced principals' perception of poor quality teaching as a form of misconduct in secondary schools. This result supports WAEC (2009) which noted that more candidates fail in their examination due to lack of quality teaching compared to what most adults got during their school days. Again, the finding also substantiates the view of Akinlabi (2012) who opined that teachers in secondary schools take delight more in discussing under trees and analyzing situations such as government policies and politics and send notes to class prefects to copy on the board for their classmates.

\section{Conclusion}

Conclusively, this study investigated Principals' Perception of Misconduct among secondary school teachers in Delta State, Nigeria. The results indicated that absenteeism, lateness, truancy and the issue of poor quality teaching are prevalent in post-primary institutions. There is need for all stakeholders in the education sector to step up efforts to stem this tide.

\section{Implications for Counselling Practice}

One of the implications of this study is that counsellors are needed in secondary schools. They are to counsel teachers on the need to take their jobs seriously and also employ behavioural techniques (such as reinforcement and modeling) to assist the teachers to unlearn undesirable behaviour such as absenteeism, lateness, truancy and lack of commitment and imbibe desirable and acceptable behaviour such as punctuality, regularity and commitment to work.

Also, guidance counsellors are the trained personnel who will help to change the irrational beliefs of some teachers who think that government work should not be taken so seriously. Through the use of Rational Emotive Behavioural Therapy (REBT), counsellors can achieve this and teachers will develop the right attitude to work.

\section{Recommendations}

Based on the findings, the following recommendations have been made:

1. On a regular basis, Inspectors from the Post-primary Education Board should pay unscheduled visits to secondary schools because this will act as a check on teachers' absenteeism.

2. Monitoring teams should be put in place by secondary schools authorities to supervise teachers' attendance in class as well as their teaching.

3. Annually, prizes should be awarded to the best behaved teachers in the various disciplines as this will motivate lazy teachers to take their work more seriously.

4. Promotion and salary increment should be based on regularity of teachers in school and the quality of teaching that is rendered as mass promotion encourages indolence and discourages dedication to work.

5. Guidance counsellors should be posted to all public secondary schools to counsel teachers on how to be intrinsically motivated.

6. Principals should demonstrate exemplary behaviour by being punctual and regular in school so that their staff could emulate them.

7. The state government should launch "War Against Indiscipline" in all post- primary institutions in Delta State and appropriate punitive measures should be meted out to defaulting teachers.

8. Federal and state governments should endeavour to make the school environment conducive so as to boost teachers' morale and increase their productivity.

9. The Counselling Association of Nigeria (CASSON), Delta State branch should in conjunction with the Post-Primary Education Board organize seminars, workshop and symposia for teachers so as to change their irrational beliefs about government work and imbibe the right attitude to their jobs.

\section{References}

Adeleke, P. (1986). "Absenteeism in Nigeria Work Organisation: A case study of selected Private \& Public Companies in Ondo State" An Unpublished M.Sc: project. Delta State University, Abraka. 
Akinlabi, J. (2012). "Though I was not trained to be a teacher" Premium Times, Thursday, December 13th, http://premiumtimesng.com/opinion/110973-ti.

Akinsanya, O. (1982). "The Nigerians' Approach to work" Nigerian Tribune, April $20^{\text {th }}$

Aronokhale, O. M. (1999). "The Effects of Workers' Attitude on Productivity in a profit-oriented organization: A case study of Leventis stores Nig. PLC" An Unpublished Post-Graduate Diploma Project, Delta State University, Abraka.

Fakoya, F.O. (2009). "Report on Teaching Profession and Factors inhibiting Teaching Profession in Nigeria" An unpublished M.Ed Project, University of Ibadan.

Federal Republic of Nigeria. (2016). National Policy on Education (Revised Edition), Lagos: Ministry of Information Press.

Fry, L. (2002). “What Makes Teachers Tick” A Policy Research Report on Teachers' Motivation in Developing Countries, London: VSC.

Kazeem, P. \& Ige O. (2010). "Redressing the growing concern of the Education sector in Nigeria". Faculty of Education, University of Benin.

Mothemane, K.D. (2004). “How Do Principals Manage Teachers' Misconduct in Public Secondary Schools”. An unpublished M.Ed Dissertation, university of Pretoria.

Oghuvwu, E. P. \& Okpilike, F.E.M. (2012). "Common Ethical issues in Delta State Schools: An Empirical Analysis. Journal of Education \& Practice, 3(13).

Onoyase, A. (2000). "Meaning and Theories of Motivation" in J.F. Egbule (Ed) Readings in Educational Psychology. Pp. 163-164.

Rossouw, J. P. (2003). "Educator misconduct and incapacity" Pretoria: Inter university Centre for Education Law, Education Leadership and Education Policy (CELP).

Schleicher, A., Siniscalco, M \& Postlethwaite, N. (1995). "The Conditions of Primary Schools: A Pilot Study in the Less Developed Countries Report to UNESCO \& UNICEF.

Solarin, T. (1982). "Attitude of Nigerian Workers to work", Nigerian Tribune, March 29.

Teachers Registration Council of Nigeria (TRCN). (2012). "Teachers Code of Conduct" (Revised Edition). Abuja: MAKJIF.

UNESCO. (2005). "Wanted one Teacher" Education Today Newsletter of UNESCO, Education Section (12).

WAEC. (2009). Report on Candidates Performance in West African School Certificate (WASC) Examination, Abuja: WAEC Office.

\section{APPENDIX \\ PRINCIPALS' PERCEPTION OF TEACHERS' MISCONDUCT QUESTIONNAIRE}

Dear Respondents,

The researcher is carrying out an investigation on principals' perception of misconduct among secondary school teachers. Please, respond honestly to the statements below. I assure you that your responses would be treated with utmost confidentiality.

Thank you for your anticipated cooperation.

Instruction: Please tick $(\sqrt{ })$ the option that applies to you.

\section{SECTION A}

1. Name of School:

2. Sex: (a) Male ( ) (b) Female ( ).

3. Location: (a) Urban ( ), (b) Rural ( )

4. Experience: (a) Principals who have been heading schools for over 10 years ( $\quad$ ) (b) Principals whose leadership experience is below 5 years $(\quad)$.

5. Age: (a) $55-60$ years ( ) (b) $48-55$ years. 


\section{SECTION B}

Please tick the appropriate answer as the case may be from the options provided.

\begin{tabular}{|c|c|c|c|c|c|}
\hline $\mathbf{S} / \mathbf{N}$ & ITEMS & $\mathbf{S A}$ & $\mathbf{A}$ & SD & $\mathbf{D}$ \\
\hline \multicolumn{6}{|c|}{ Absenteeism } \\
\hline 1. & $\begin{array}{l}\text { It is now a common practice for secondary school teachers to stay away } \\
\text { from work many days in a month. }\end{array}$ & & & & \\
\hline 2. & $\begin{array}{l}\text { A good number of teachers are absent from their workplace without } \\
\text { permission from their principals. }\end{array}$ & & & & \\
\hline 3. & $\begin{array}{l}\text { Some teachers are absent from school in order to run their own } \\
\text { business. }\end{array}$ & & & & \\
\hline 4. & Absenteeism of teachers in secondary schools is on the increase. & & & & \\
\hline 5 & $\begin{array}{l}\text { Teachers stay away from school for flimsy reasons without any } \\
\text { consideration for their students. }\end{array}$ & & & & \\
\hline \multicolumn{6}{|c|}{ Lateness to School } \\
\hline 6. & $\begin{array}{l}\text { In my school, many teachers don't participate in morning assembly } \\
\text { because of lateness. }\end{array}$ & & & & \\
\hline 7. & Some teachers come to school when the first lesson is almost over. & & & & \\
\hline 8. & Teachers are not perturbed about their persistent lateness to school. & & & & \\
\hline 9. & $\begin{array}{l}\text { Constant lateness of teachers to school may be as a result of their } \\
\text { orientation about Government's work }\end{array}$ & & & & \\
\hline 10. & $\begin{array}{l}\text { Lateness of teachers to school may be due to unconducive work } \\
\text { environment. }\end{array}$ & & & & \\
\hline \multicolumn{6}{|c|}{ Truancy } \\
\hline 11. & $\begin{array}{l}\text { Some teachers leave the school after signing the time-book and only } \\
\text { appear to sign off at the end of the day. }\end{array}$ & & & & \\
\hline 12. & $\begin{array}{l}\text { Shortly after their arrival in school, some tutors leave without } \\
\text { permission and stay away for the remaining part of the day. }\end{array}$ & & & & \\
\hline 13. & $\begin{array}{l}\text { Some teachers do not remain in school till the close of the day because } \\
\text { they are poorly motivated. }\end{array}$ & & & & \\
\hline 14. & Some tutors are fond of leaving school to sell their wares. & & & & \\
\hline 15. & Sneaking out from school by teachers is seen as a "normal" practice. & & & & \\
\hline \multicolumn{6}{|c|}{ Poor Quality Teaching } \\
\hline 16. & $\begin{array}{l}\text { A good number of teachers do not write lesson notes and so they are } \\
\text { ill-prepared for lessons. }\end{array}$ & & & & \\
\hline 17. & $\begin{array}{l}\text { Secondary school teachers no longer make their lessons interesting by } \\
\text { using teaching aids. }\end{array}$ & & & & \\
\hline 18. & $\begin{array}{l}\text { Many teachers go to class when half of the period has passed and } \\
\text { consequently do not finish the syllabus. }\end{array}$ & & & & \\
\hline 19. & $\begin{array}{l}\text { Some teachers have formed the habit of sending notes to class prefects } \\
\text { to copy on the board (for their classmates) without actually teaching. }\end{array}$ & & & & \\
\hline 20. & $\begin{array}{l}\text { Selling of goods by teachers during official hours encroach into their } \\
\text { periods and therefore do not have enough time to teach their lessons. }\end{array}$ & & & & \\
\hline
\end{tabular}

